Man and Nature

L'homme et la nature

\title{
Bibliographical Control of Eighteenth-Century French \\ Canadiana
}

\section{William J. Cameron}

Volume 1, 1982

URI : https://id.erudit.org/iderudit/1011798ar

DOI : https://doi.org/10.7202/1011798ar

Aller au sommaire du numéro

Éditeur(s)

Canadian Society for Eighteenth-Century Studies / Société canadienne d'étude du dix-huitième siècle

ISSN

0824-3298 (imprimé)

1927-8810 (numérique)

Découvrir la revue

Citer cet article

Cameron, W. J. (1982). Bibliographical Control of Eighteenth-Century French Canadiana. Man and Nature / L'homme et la nature, 1, 131-151.

https://doi.org/10.7202/1011798ar

Copyright (c) Canadian Society for Eighteenth-Century Studies / Sociéte canadienne d'étude du dix-huitième siècle, 1982
Ce document est protégé par la loi sur le droit d'auteur. L'utilisation des services d'Érudit (y compris la reproduction) est assujettie à sa politique d'utilisation que vous pouvez consulter en ligne.

https://apropos.erudit.org/fr/usagers/politique-dutilisation/ 


\section{Bibliographical Control of Eighteenth-Century French Canadiana}

An interdisciplinary volume like the present one is an ideal opportunity to attempt to jump the fences which the departmental structure of universities seems to have placed around the activities of scholars of a particular period of intellectual and cultural history. Even more important is the possibility of sharing insights between two or more disciplines when the barriers of subject and languge departmentalism are temporarily lowered. I want you first of all to look over your fence into the yard of library science. Some of the conceptualizations and theories being developed there owe a great deal to other disciplines but the practical application of some of the theory is to be found in many other people's yards. I have recently been applying an evolving theory of bibliographical control to the field of French Canadiana; I hope it will be of equal value in language departments other than French, and in subject departments other than Canadian history or literature. Indeed, it has significance well beyond even the cross-disciplinary field of the eighteenth century which brings us together. In order to make points about the eighteenth century I shall need to range into sixteenth and seventeenthcentury areas as well and to make some remarks about the concepts of "bibliographical control" and "bibliographical universe."

The bibliographical universe consists of millions and millions of objects which we designate books, pamphlets, periodicals, maps, manuscripts, sheet music, etc.; for some people the universe would include postage stamps, theatre tickets, or any piece of paper or other material with human-produced signs on it, made with an enormous range of implements - from a sharp piece of stick to a printing press or a high-speed computer-driven machine. The very act of attempting an exhaustive list of either the categories of product or the categories of means of production would constitute a form of bibliographical control. Classification is a basic instrument of bibliographical control. Each individual object in the bibliographical universe can be assigned to a class, even though we would not find universal agreement on what are the most important or useful classes. Nevertheless, instinct tells us that the number of classes cannot be very great in number. S.R. Ranganathan stated in $1953^{1}$ that any attempt to list all items in the bibliographical universe is impractical, but he proceeded to suggest that some usable substitutes for universal lists are certainly within the realm of possibility. In his book Documentation and its Facets (1963), ${ }^{2}$ Ranganathan 
spelled out five characteristics which might form the basis for restricting an "omnibus universal documentation list" to usable lists. I took the liberty in 1976 to expand these five characteristics to six and proceeded to divide them further into two classes. Reflection since then has led to the identification of three more and I am sure there are others. These generic characteristics still seem to fall into two main classes.

Those of you who want a more thorough investigation of the theoretical framework within which I will be proceeding, might like to struggle with the first chapter in The Bibliographical Control of Early Books (Bangalore, India, 1978). ${ }^{3}$ There, in some close argumentation, I attempt to build upon, but modify, the fine philosophical endeavours of Patrick Wilson, in his Two Kinds of Power: An Essay on Bibliographical Control (Berkeley: University of California, 1968). ${ }^{4}$ Wilson attempts to establish, with Carnap as his guide, a philosophical underpinning for the common use or uses of the term. But before using Wilson's ideas, let me state what the nine "characteristics" derived and expanded from Ranganathan are:
A Area of origin of the documents
B Language of the documents
C Period of production of the documents
D Physical process by means of which the documents were produced
E Author or group of authors of the documents
F Present location of the documents
G Subject of the documents
$\mathrm{H}$ Standard or quality of the documents
I Service aimed at by the documentation lists

When trying to classify objects in the bibliographical universe according to these limiting characteristics, we might note that the first six require a predominantly objective kind of judgment, while the other three imply a judgment of a more subjective kind in which knowledge of the purposes in the mind of the users of the list is all-important.

This distinction owes a great deal to Wilson's "two kinds of power" as it is based upon his maintenance of "our common-sense distinction between powers whose exercise requires appraisal and those whose exercise requires only bare description." Although I have asserted a more subtle interrelationship between what he calls "exploitative" and "descriptive" power than he is willing to accept, I thoroughly agree with Wilson that bibliographical control is a power, the power that can be exercised by individuals over a part or the whole of the bibliographical universe. And I agree that that power is both descriptive and evaluative. But I place much more emphasis than he on the primacy of descriptive power. Without thorough and accurate description, appraisal is arbitrary and partial.

Wilson, in pursuing his enquiry, asks a key question (beginning of Chapter II):

What might a person be able to do or have done to things in the bibliographical universe that would count as exercises of the power we call "bibliographical control"? 
It seems to me the primary exercise of the power is to name and count those things. How powerful is your control? What eighteenth-century items of Canadiana are you able to name? How many are there? Let us use these questions to explore our chosen part of the universe.

The alternative phrase in Wilson's question, "to do or have done to," implies an instrument of power, so the concept of bibliographical instrument is fully discussed in Wilson. The most familiar bibliographical instrument is a list of books and articles arranged in a convenient, browsable and meaningful order - the familiar "bibliography" in its many printed and manuscript forms. But the development of machine-readable bibliographical data bases, with a theoretically infinite variety of possible forms of display is beginning to complicate (but in some ways also to simplify) the traditional forms of bibliographical instruments, or 'bibliographical tools' as the jargon of library and information science would have it. One needs a strong theoretical framework if one wishes to design a computer-based bibliographical tool that will optimize our bibliographical control over even a part of the bibliographical universe. That part of the universe which I want to exercise power over is limited by four of the nine characteristics mentioned above - to books printed in the French language, on a hand-operated letterpress machine, during the eighteenth century, on subjects relating to the geographical area we now call Canada. It should also be possible in the ideal bibliographical instrument to derive listings characterized by the other five as well. Moreover, the computer-based bibliographical tool that we ought to create must be capable of bibliographical control of other parts of the bibliographical universe in addition. The impracticality of attempting control of the whole of that universe has led me to design a system for control only of letterpress books printed before 1801, thus making a rational application of Ranganathan's classificatory underpinning. Attention to Wilson's very important distinction between descriptive and exploitative power has led me to incorporate access or indexing devices that will optimize the combination of those powers. The distinction should be kept in mind when assessing existing bibliographical tools as well as when imagining a more powerful one in machine-readable form. The computer should not be used as a mere mechanical substitute for human labour, but a "telescope of the mind" as one writer has put it. Just as the telescope enabled man to see things he could not see with the naked eye, the computer ought to be able to extend the use of the human mind, especially making use of the elusive elements of human memory that all forms of recorded knowledge exemplify.

With these thoughts in mind, I have been developing a computer-based bibliographical tool that should significantly improve our bibliographical control over French-language Canadiana before 1801, and, at a second stage, over French, Spanish, and Portuguese Americana, i.e. Western Hemispheriana in those three languages. Eventually, the system should be expandable to cover all letterpress production before 1801. Before imagining what the developing system should be able to do, and before describing what it can do now, a survey of what existing manually-based tools can do for us should be attempted. 
The first requirement for minimal bibliographical control of Frenchlanguage Canadiana of the eighteenth century would be an exhaustive list of all items in our limited part of the bibliographical universe enabling us both to identify and count those items. Although the definition of "Canadiana" is fraught with difficulties, the selection of items is a fairly simple exercise of appraisal: the choice of data for representing each item is an exercise of neutral "descriptive" power. The publication that comes nearest to an ideal tool is Tremaine's Bibliography of Canadian Imprints $1751-1800 .^{5}$ It is limited by (A) area of origin of the documents, (C) period of production, (D) physical process and to a certain extent (F) location. Even though the French-language and bilingual items are scattered among items in English or other languages, we may easily impose limitation (B) and isolate 546 items in roughly chronological order in the listing. (I should note in passing that no bibliography in our field is strictly chronological. Books of the same year of publication are nearly always listed in conventional author/title order, so the arrangement should probably be called more accurately "annalistical" rather than chronological.)

Although a small number of items has been and will eventually be found to augment Tremaine, it is safe to assume (an act of "appraisal") that this tool is very close to the ideal in exhaustive listing, for it includes items for which no surviving copy has been found. The index in the back of the book, however, leaves much to be desired when one wishes to apply our four other limitations and thus to exercise "exploitative" power as distinct from "descriptive" power.

Canadiana printed outside Canada have been listed in a large number of bibliographical tools, but none is comparable with Tremaine's listing of Canadian imprints. Tremaine's listing supersedes earlier partial attempts at chronological listings, such as Dionne's, which has at least one feature that makes it a better tool of bibliographical control. Dionne's Tome I (1905) ${ }^{6}$ is limited to French-language items printed in Quebec. However, with 62 items between 1765 and 1800, his coverage is poor. (It is noteworthy, however, that the shortness of the individual entries makes scanning much more feasible than in Tremaine.) No annalistical bibliography supersedes Dionne's companion volume of imprints printed outside Quebec. ${ }^{7}$ Although this Tome II includes 909 items before 1801, only 336 are, on rough count, in the French language. The words "rough count" are necessary because the language of some entries is not indicative of the language of the text, so precision is not feasible.

One of the major advantages of the annalistical or pseudo-chronological arrangement of Dionne and Tremaine is that we can select those items printed within a set period of time. For instance, Dionne lists roughly 131 French-language items of Canadiana that were printed between 1701-1750, and 101 between 1751 and 1800. If the user of a bibliographical tool were attempting to locate contemporary printed works covering, for instance, the Seven Years' War, this would greatly improve his bibliographical control. A subtle variation on the annalistical arrangement would improve it even more. One bibliography attempts to list all items according to the date of the contents of the book, even though first publication of the work may have been decades or even centuries later. This is Staton \& Tremaine's Bibliography of 
Canadiana, ${ }^{8}$ a catalog of the Canadiana in the Toronto Public Library (now the Reference Library of the Metropolitan Toronto Library System). The 749 items before 1801 (in many languages) are in fact listed by the conventional author/title arrangement within each of the years, so the book can be read as the annals of Canadiana. Unfortunately, however, the actual coverage of French-language items is limited to the holdings of one library. A rough count made by quick scanning of the language of the title pages both in the bibliography and its 1959 Supplement, 9 indicates that about 287 of the 897 items before 1801 are probably in the French language. About 45 belong in the first half of the eighteenth century, but a considerable number of Canadian imprints are included in the 128 or so of the second half of the eighteenth century. If we discount nineteenth and twentieth-century imprints, this fine bibliography can compare favorably with Dionne for comprehensiveness only in the second half of the eighteenth century. However, the detailed general index to the text provides access points (other than annalistical) greatly superior to Dionne, but still well below the level needed for reasonable exploitative bibliographical control.

A bibliography based on a single library's collection is a severe limitation on the comprehensive element of bibliographical control that we are presently concentrating on. A union catalog (such as The National Union Catalog: Pre-1956 Imprints) ${ }^{10}$ tends, on the other hand, to scatter items of our limited portion of the bibliographical universe among a preponderance of nonrelevant items. Nevertheless, the limited tool, when used as an access device to the more comprehensive tool, frequently improves the quality of both tools as an instrument of bibliographical control. For this reason, NUC: Pre-1956 Imprints can be used as the most comprehensive listing of French Canadiana, but only in combination with more limited bibliographies organized on different principles. In general, then, a scholar wishing to exercise bibliographical control over a limited portion of the universe must use a number of even more limited bibliographical tools, despite the fact that they, too, frequently include non-relevant items.

Several lists of bibliographies of Canadiana are available, but all suffer from the same problem that union catalogs present to us. The Bibliothèque Nationale du Québec, for instance, has published a Bibliographie de bibliographies québécoises (1979). ${ }^{11}$ The power of selecting bibliographies limited by the time and the language of the original items listed is not facilitated by the predominantly nineteenth and twentieth-century contents of most of the bibliographies listed, however, and the place limitation (Quebec) limits our access to items for the whole of Canada. Lochhead's Bibliography of Canadian Bibliographies (2nd ed., 1972) ${ }^{12}$ transcends the space limitation, and provides readier access to major bibliographies of the kind most pertinent to our purposes partly because Peter Greig's index of subjects, localities, authors, and compilers helps to chart scope limitations.

Most of the largest bibliographies of Canadiana are in fact printed catalogs of individual collections, either of bookcollectors or of libraries. None of them is exactly alike in arrangement, scope, or bibliographical treatment of individual items. The very range of possibilities provides the designer of a computer-based bibliographical instrument with a host of ideas for imagining 
what devices might be incorporated in the system for maximal exploitative bibliographical control.

Laurentiana parus avant $1821^{13}$ is probably the most useful bibliographical instrument for determining what Canadiana in French appeared before 1801, as it is a full-scale bibliographical catalog of 770 items in the largest single Canadian repository that has published such a catalog. But it is also useful because it has a larger number of different means of access to information contained in the catalog than is to be found in other printed catalogs.

The catalog proper of 416 pages, although arranged in conventional author/title/date order, can be used with reasonable convenience within four of our nine limiting characteristics, but the following indexes provided in the back of the book extend that convenience to encompass three others:

$\begin{array}{cl}\text { Index des titres } & (15 p) \\ \text { noms } & (26 \mathrm{p}) \\ \text { matières } & (21 \mathrm{p}) \\ \text { illustrations } & (6 \mathrm{p}) \\ \text { cartes et plans } & (8 \mathrm{p}) \\ \text { lieux d'édition } & (15 \mathrm{p}) \\ \text { imprimeurs } & (8 \mathrm{p}) \\ \text { dates de l'édition } & (16 \mathrm{p})\end{array}$

The latter index provides information that can easily be scanned to identify and count (with the usual imprecision) items before 1801 in French. The total number is 263 (almost as rich as Dionne). No other printed library catalog can be so easily used to gain this simplest form of bibliographical control over the portion of the bibliographical universe that we are interested in. The Lawrence Lande Collection of Canadiana in the Redpath Library of McGill University has been catalogued in a sumptuous volume ${ }^{14}$ in which the 2328 items are arranged in three categories, each of which is also arranged in conventional author/title/date order. The three categories are:

Basic Canadiana (915 items)

Canadiana in the West and North (608 items)

Cultural and Supplementary Canadiana (805 items)

The indexes at the end of the book are idiosyncratic:

Bibliographical Index (largely a nominal index of authors, both personal and corporate) (8p)

Index to Government Documents (largely an index to localities both as subject and source of the douments) (3p)

Title index (17p)

Subject index (7p)

One must search sequentially through the whole book to identify Canadiana in French printed before 1801, a very time-consuming process. A first rough count established that 32 French-language Canadian imprints and 124 other French-language Canadian items are listed. It would be very tedious to attempt to further subdivide the latter 124 into pre-1701 and eighteenth- 
century items. However, the rough count suggests that the McGill collection is only half as rich as the BNQ collection.

Rare and Unusual Canadiana, ${ }^{15}$ the first supplement to the Lande bibliography, was published in 1971 in not quite so sumptuous a form, but again in conventional author/title/date order, thus making it comparable with Laurentiana and the three categories of the Lande bibliography. The first 667 pages contain 2335 items, and the next 67 pages an addendum of 206 items. An author index and a title index are provided, together with a "Special Subject Index" which intermingles broad subject headings with form (e.g. Broadsides, Circulars and Ephemera) and chronological headings (e.g. French Regime). Among the chronological headings is "Early Canadian Imprints dating up to 1800," but the addresses for the items are not themselves in chronological order. Once again, a sequential search through the thousands of items is required to discover what proportion might be Canadiana in French before 1801, or between 1700 and 1800 (or any other desired period). The figures are 53 French-language Canadian imprints and 110 other French-language items of Canadiana. McGill is beginning to rival BNQ!

Older catalogs and bibliographies are of varying quality and convenience for satisfying our modest desire for at least a simple quantitative answer to our original questions.

However, this is not meant to be a survey of all bibliographical tools, so we need not go on to analyse Gagnon, Faribault, and other tools of less comprehensive scope. But some brief comments on the amount of information provided in a range of the most useful tools is in order. In Bibliographical Control of Early Books I made the distinction between macroscopic and microscopic bibliographical control, with very detailed examples to illustrate the distinction. I shall give here only one or two examples from bibliographies of French Canadiana. Dionne is a fine example of macroscopic bibliographical control - he approaches more closely than any other bibliographer the criterion of comprehensiveness or exhaustivity, and he achieves this by reducing individual entries in his listing to minimal description. McCoy, in his Jesuit Relations of Canada (1937) ${ }^{16}$ is a fine example of microscopic bibliographical control - he provides 132 entries for the 50 or so texts that constitute the $1632-1673$ series of reports. Although his categorization of variations can be faulted by application of modern analytical techniques, McCoy has provided more detailed bibliographical analysis of individual copies of a group of French Canadian books than any other bibliographer, including his predecessors Harrisse or Cole, who provide more detail on the content of the books they describe. Dionne provides a rather skimpy "Table des Matières" which is derived completely from the information provided in his entries, not from the books themselves.

When considerable bibliographical detail in an entry is accompanied by valuable annotations (as in Staton \& Tremaine) such derived indexes can be a valuable tool for bibliographical control. Indexes of information in the actual books for which the entries are a surrogate would improve our control even further, but, in practice most indexes to bibliographies provide information that is contained only in the surrogate or its accompanying annotations. Such 
limitations of a manually-produced bibliographical tool should not limit our approach to indexing devices in a machine-based system. Thus, a macroscopic tool like Dionne's could be complemented by indexing devices which add information to the minimal amount given in an entry designed for ease of scanning.

Observed weaknesses of existing bibliographical instruments make it highly desirable that the Western Hemisphere Short-Title Catalog system (WHSTC) will be essentially a macroscopic bibliographical control instrument with indexing features built into it so that the microscopic bibliographical control provided by other bibliographical tools can be made available by referral. A brief overview of the WHSTC system, with its retrieval and indexing program called "NOBLE" will suggest how this is being done.

First of all, a working definition of what constitutes an item or individual unit in the bibliographical universe has been devised. This is called a "bibliographically distinct volume." Second, rules for creating a record or surrogate for each 'bdv' have been devised. It is essentially an adaptation of a traditional short-title catalog record, and it is meant to identify not to describe a 'bdv'. It is also meant to be an index term for referring to other kinds of surrogates recorded in catalogs, bibliographies, and checklists. Third, the basic machine-readable files of the system are cumulated in a series of main files that are accessed through 26 "control" files by a user of the system. The user can employ a large number of "browsing files" which will maximize his or her power of selection, and a large number of "query files" which will maximize his or her power of aggregating records into a machine-produced bibliography. If you wish to have details of how the system works and is evolving, you might like to read The HPB Project: Phase IV. ${ }^{17}$ The major end-products of the on-line system are bibliographies, annotated or unannotated, in various stages of development, which are generated from a "query file." These query files will proliferate as the system responds to the needs of users for exploitative bibliographical control. I have reproduced the bibliographies generated from two of these for illustration. They represent bibliographies in a transition stage from 'descriptive' to 'exploitative'. Both bibliographies require annotations representing appraisal of subject, quality, and potential use. More descriptive data may also be needed.

I have supplied the seventeeth-century bibliography for contrast with the less-well-developed eighteenth-century bibliography, but both have features in common that should be commented on first. The user of the system is first confronted with a "menu" and invited to choose among eight possibilities which are strongly related to the nine "characteristics" of limitation, derived from Ranganathan.

What point of access to the WHUC database do you want? (type the letter corresponding to its description):
A Anonymous titles
P Personal authors
C Corporate authors
L Localities 

S Subjects
F Forms
O Others
E Exiting from system

Although "FORM" then "RELATIONS" was chosen in this instance for the seventeenth-century listing, the so-called "tracings" under the heading of query file Q0011 indicate other possible access points.

Type first word of the form you seek otherwise type 0 for none or type ? for index: relations

1) RELATIONS

\section{Q0011,Q0055}

2 specifications. 1 pages.

Which page do you wish to read? Type the number of the page you seek otherwise type 0 for none or press RETURN for all records:
Jesuit relations
Q0011
Recollet relations
Q0055

If you would like more information about one of these items, please type the numerical information as it appears against that item. If not, type NO: Q0011

JESUIT RELATIONS. Chronological listing of accounts of events in Canada, 1632-1673, sent by Jesuit missionaries to France

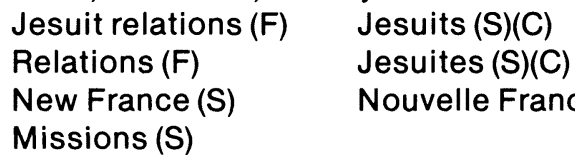

56 addresses

Type in the letter corresponding to your wishes:

$P$ the bibliography printed out

$S$ the bibliography stored for COM

$\mathrm{N}$ none of the above

\section{? $\mathrm{n}$}

Just to hint at the browsing possibilities, I have chosen "TITLE" and "LETTRES" as a first exploratory decision for finding the eighteenth-century listing, but used a more specific "FORM" approach as an alternative. Again, the tracings will suggest other alternatives, but more important still, will suggest access points to other query files that might be relevant to the user's purpose in retrieving this particular bibliography.

? a

Type first word of title you seek (avoid use of article) otherwise type 0 for none or type ? for index: lettres

1) LETTRES

L0300342-995, A0148179-95, 201-10, C0752044*-6, D0440313-9*, 
F0206450-0*, J0092998*-3021*, 200398, L0028668*, M0726808-13, $5-9,22^{*}, \mathrm{R} 0166593-4^{*}, \mathrm{~S} 0029845-50,2$

17 specifications. 1 pages.

Which page do you wish to read? Type the number of the page you seek otherwise type 0 for none or press RETURN for all records:

Lettres a M. le marquis de L. C. L0028668* monsieur $\mathrm{N}^{\star \star \star} \quad 371^{*}$

curieuses touchant la religion $\quad \mathrm{J} 0200398$

d'amour d'une religieuse $\quad A 0148179^{*}, 82^{*}$

d'Heloise a Abailard 486*

d'un francois a un hollandais $\quad 521-2$

d'une demoiselle entretenue $\quad \mathrm{C}^{2} 752044^{*}-5$

religieuse portugaise A0148179*

Turque a Paris $\quad 50029847$

de la Fillon C0752046

ecrites d'Anvers par un officier $705^{*}$

edifiantes et curieuses J0092998*-3021*

galantes et philosophiques R0166593-4*

historiques et galantes D0440313-9*

persanes M0726808-13,5-9,22*

sinceres d'un gentilhomme F0206450-0*

turques S0029847*-50

If you would like more information about one of these items, please type the numerical information as it appears against that item. If not, type NO: no

What point of access to the WHUC database do you want? (type the letter corresponding to its description):
A Anonymous titles
$P$ Personal authors
C Corporate authors
L Localities
S Subjects
F Forms
O Others
E Exiting from system

$? \mathrm{f}$

Type first word of the form you seek otherwise type 0 for none or type ? for index:?

Type a letter to set all entries beginning with that letter: I

5 records. 1 pages.

Which page do you wish to read? Type the number of the page you seek otherwise type 0 for none or press RETURN for all records:

LAWS

LEITOURGIKON 


\section{LETTERS}

\section{LETTRES}

\section{LITURGY}

Type first word of the form you seek

otherwise type 0 for none or type ? for index: letters

\section{1) LETTERS}

\section{Q0034}

1 specifications. 1 pages.

Which page do you wish to read? Type the number of the page you seek otherwise type 0 for none or press RETURN for all records:

From Jesuit missions Q0034

If you would like more information about one of these items, please type the numerical information as it appears against that item. If not, type NO: Q0034

JESUIT LETTERS FROM MISSIONS. Chronological listing of 18th century publications

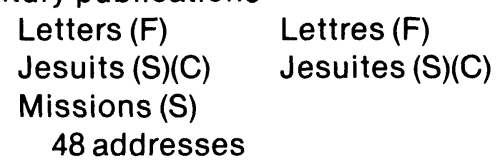

Type in the letter corresponding to your wishes:

$P$ the bibliography printed out

$S$ the bibliography stored for COM

$\mathrm{N}$ none of the above

? $\mathrm{p}$

\section{1}

J0092998* 50

[description not yet on file]

[Vol I, Le Clerc, 1702] [OCIWHi]

\section{2}

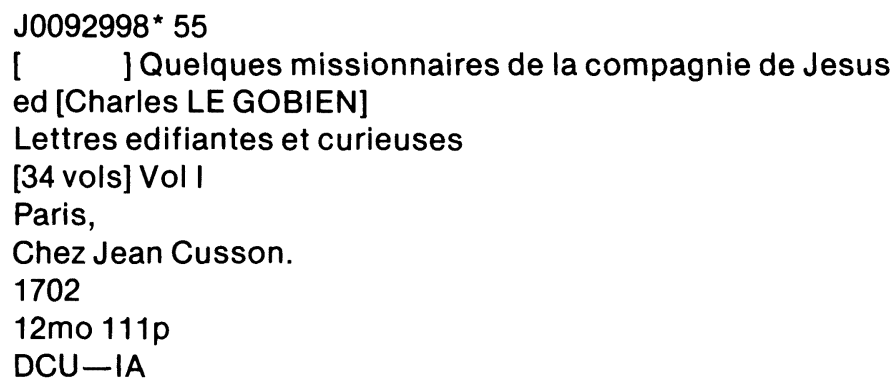




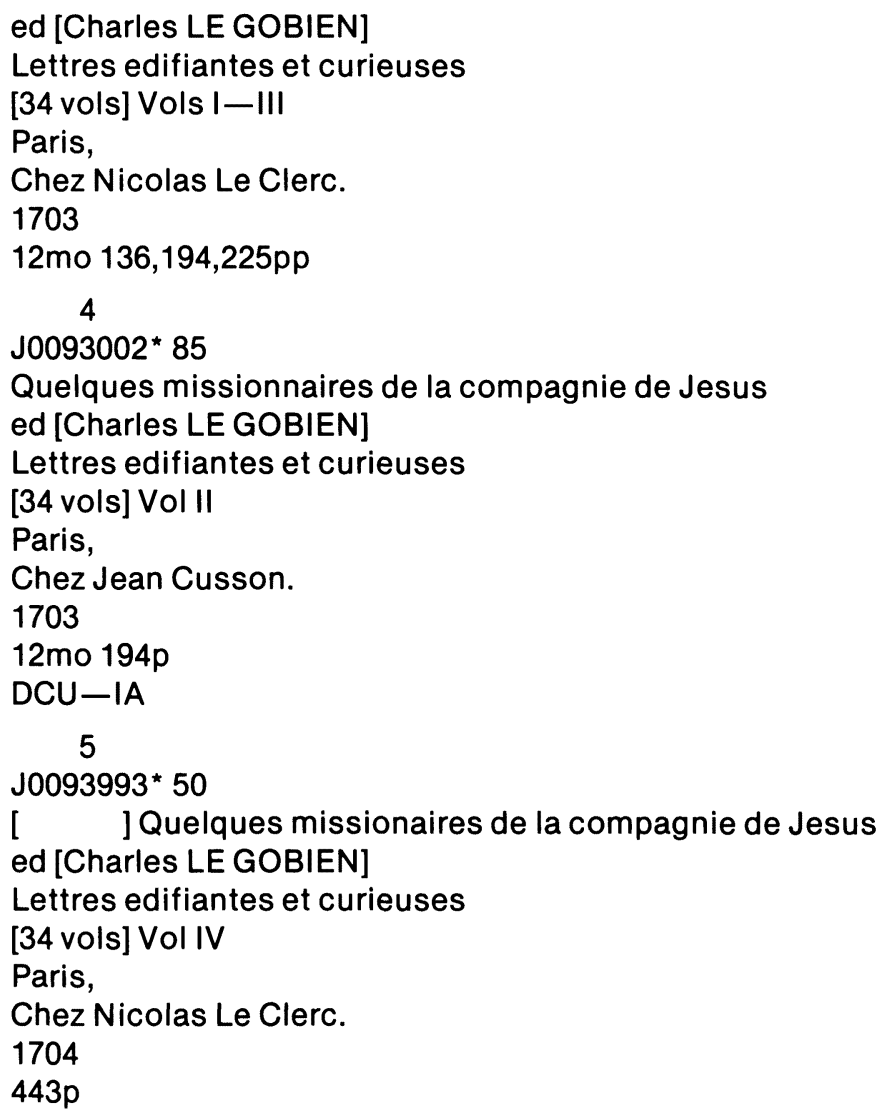

Each entry in both bibliographies consists of a short-title catalog entry selected by the machine from the "main" files. Each entry is preceded by two addresses and (optionally) an annotation; it may be followed by a list of library holdings and (optionally) another annotation. The list of library holdings comes from the 'control' file, which also instructed the machine what entry to select from the 'main' files. All the other information comes from the 'query' file.

A computer program has been used to give identifying addresses to each entry in the bibliographies (1-56 and 1-48), but a reference to the best available bibliographical description in another bibliography could be substituted if that would improve our bibliographical control. For instance, references to Harrisse ${ }^{18}$ could be substituted in the seventeenth-century bibliography, or references to Conlon ${ }^{19}$ could be substituted for the following 11 WHSTC addresses in the eighteenth-century bibliography:

$\begin{array}{cc}\text { WHSTC } & \text { Conlon } \\ 1 \text { and } 2 & 11035 \\ 3 & 11553 \\ 5 & 12046\end{array}$




$\begin{array}{rr}6 & 12608 \\ 7 & 13082 \\ 8 & 13585 \\ 9 & 14113 \\ 11 & 15640 \\ 12 & 16636 \\ 17 & 17738\end{array}$

This would make it possible to consult Conlon's notes on each first edition. Although the cross-reference would also reveal that Conlon's description of each item does not identify the item as accurately as the short-title catalog entry (e.g. items 1 and 2 are not distinguishable), it would also reveal subtle differences that provide new information (e.g. Conlon 11553 lists only the first edition of Vols II-III, but WHSTC 3 suggests the possibility that they were issued simultaneously with a reprint of Vol I).

The second address is what we call the WHUC (i.e. the Western Hemisphere Union Catalog) address. It is derived from an address in NUC: Pre-1956 Imprints, to which the user is automatically referred if he or she wishes to find a regular library catalog description of the item, and a list of libraries in the U.S. (and occasionally Canada) where the item may be found. If the first 8 characters of the address are followed by an asterisk, the item is not described in NUC. Thus, in the seventeenth-century bibliography, WHSTC 28 and 39 are either subsumed in some other entry or are not recorded in NUC. In the eighteenth-century bibliography, the high proportion of entries with asterisks indicates that NUC has subsumed most bibliographically distinct volumes within sets of the 34-volume work, thus making identification of different editions virtually impossible. The last three characters in the WHUC address represent date of publication if the item is in NUC, and filing and individuation numbers for the machine if it is not.

We might concentrate on the differences between the two bibliographies rather than the similarities in order to put the eighteenth-century one into perspective.

Not everything in the two bibliographies is French-language Canadiana. In the seventeenth-century one, the language of $27,29,33$, and 34 makes it obvious that they would be excluded. Everything in the eighteenth-century list is obviously in French, but the descriptive annotations inserted for illustrative purposes in the last three entries indicate that only No. 47 among the three contains Canadiana.

Memoires du Levant, vols 1-5:

46

J0093018* 99

[ ] ]

ed [Yves Mathurin Marie TREAUDET DE QUERBEUF]

Lettres edifiantes et curieuses

New edn

[26 vols] Vols I-V

Paris,

Chez G. Merigot le jeune. 
1780

$12 \mathrm{mo} 453,483,480,496,534 \mathrm{pp}$

TXU CaOLU CaQMBN

Memoires d'Amerique, vols 6-9; des Indes, vols 10-15; de la Chine, etc., vols 16-24:

47

J0093021*40

[ ]

ed [Yves Mathurin Marie TREAUDET DE QUERBEUF]

Lettres edifiantes et curieuses, ecrites des missions

New edn

[26 vols] Vols VI-XXIV

Paris,

Chez J.G. Merigot le jeune.

1781

$12 \mathrm{mo} 424,456,424,416,404,423,448,463,400,430,438,452,480$, $516,462,526,532,619,552 \mathrm{pp}$

TXU CaOLU CaQMBN*

Memoires des Indes et de la Chine, vols 25-26:

48

J0093021*60

[ ]

ed [Yves Mathurin Marie TREAUDET DE QUERBEUF]

Lettres edifiantes et curieuses

New edn

[26 vols] Vols XXV-XXVI

Paris,

Chez J.G. Merigot le jeune.

1783

$12 \mathrm{mo} 444,518 \mathrm{pp}$

TxU CaQMBN* CaOLU

A similar annotation upon geographical coverage added to each entry in the query file would enable us to make a decision that WHSTC 12, 17, 18, 19, $20,26,32,34,36$ contain Canadiana. Simple descriptive annotations of this kind can be augmented with evaluative ones, but might be better reserved for the nine items as they appear in the Canadiana query file. Simple appraisal of the descriptive elements in both bibliographies helps us to decide what should in fact be selected for inclusion in other query files. More evaluative annotations can serve other purposes.

The seventeenth-century bibliography illustrates how we can optimize our macroscopic bibliographical control by reducing the descriptive detail of McCoy to minimal identificatory data. No real loss in microscopic bibliographical control has taken place despite the fact that McCoy's 132 entries have been reduced to 56 . Indeed, microscopic bibliographical control can in fact be increased by adding interpretative or evaluative annotations to the query file. To illustrate this, McCoy's first 27 entries have been appraised, 
and bibliographical annotations added to the first ten WHSTC entries. Evaluative content notes could also be added before or after each WHSTC entry in order to improve our exploitative power. Some might with profit be derived from Harrisse.

$$
1
$$

L0235511 632

LE JEUNE, Paul

Brieve relation dv voyage de la novvelle France

Paris,

Chez Sebastien Cramoisy.

1632

8 vo 68p

McCoy distingujishes 2 variations: 1,2

McCoy gives details of 3 textually insignificant variant states of forme $A(0)$

2

L0235531 634

LE IEUNE, Paul

Relation de ce qui s'est passe . . .1633

Paris,

Chez Sebastien Cramoisy.

1634

8 vo $216 p$

McCoy distinguishes 2 edns: 1st, 3,4,5; 2nd 6-9. This is 1 st edn CaQMBN

McCoy gives details of a textually significant variant state of formes $\mathrm{H}(\mathrm{i} \& \mathrm{O})$ and $\mathrm{O}(\mathrm{O})$, and an insignificant one of $\mathrm{A}(\mathrm{O})$

3

L0235534 634

LE IEUNE, Paul

Relation de ce qvi s'est passe...1633

Paris,

Chez Sebastien Cramoisy.

1634

8vo 216p

McCoy distinguishes 4 variations of 2 nd edn: 6,7,8,9

McCoy gives details of a textually significant variant state of formes $\mathrm{H}$ (i) and $\mathrm{O}(\mathrm{O})$, and an insignificant one of $\mathrm{A}(\mathrm{O})$ and $\mathrm{E}(\mathrm{O})$

4

L0235539 635

LE IEUNE, Paul

Relation de ce qvi s'est passe. . .1634

Paris,

Chez Sebastien Cramoisy.

1635

8 vo $342 p$ 
McCoy distinguishes 2 edns: 1st edn, 10,11,12,13; 2nd edn: 14 CaOOP CaQMBN

1st edn: McCoy gives details of a textually significant variant state of forme $X$ (i) and an insignificant one of $E(i)$ and I(i); 2nd edn: McCoy gives details of a textually significant variant state of forme $Y(0)$ and possibly of a cancel A2

5

L0235543 636

LE IEUNE, Paul

Relation de ce qui s'est passe. . .1635

Paris,

Chez Sebastien Cramoisy.

1636

8 vo $246 \mathrm{p}$

McCoy distinguishes 4 variations: $16-19$

CaQMBN

McCoy gives details of 3 or 4 textually significant variant states of forme $E(0)$ and of a textually significant variant state of $F(i)$

6

L0235542 636

LE IEUNE, Paul

Relation de ce qvi s'est passe. . .1634. \& 1635

Avignon,

De l'imprimerie de laqves Bramereav.

1636

8 vo $416 \mathrm{p}$

McCoy 15 distinguishes no variants, but gives second part a distinct number: 20

McCoy claims Part II is a reprint of his $16-19$

\section{7}

L0235547 637

LE IEUNE, Paul

Relation de ce qvi s'est passe. . .1636

Paris,

Chez Sebastien Cramoisy.

1637

8 vo 272,223p

McCoy distinguishes 2 edns: 1 st, 21,22; 2nd, 23. This is 1 st edn

CaOTU

McCoy gives details of a textually significant variant state of formes $\mathrm{Ee}(\mathrm{O}), \mathrm{li}(\mathrm{i}), \mathrm{Kk}(\mathrm{i})$

8

L0235551 637

LE IEUNE, Paul

Relation de ce qvi s'est passe. . .1636

Paris, 
Chez Sebastien Cramoisy.

1637

8vo 199,163pp

McCoy 23 distinguishes no variants

9

L0235555 638

LE IEUNE, PavI

Relation de ce qui s'est pass[e]. . .1637

Roven,

Chez lean Le Bovllenger.

1638

8vo 336,256pp

McCoy distinguishes 4 variations: $24,25,26,27$. This is McCoy 24 and 25 (two distinct issues)

CaOOP CaQMBN

McCoy gives details of a textually significant variant state of formes $E(0), H(0), P(0), T(0), A a(0)$ and an insignificant one of $L(i), O(0)$, and $A a(i)$. $\mathrm{He}$ also gives details of 4 textually significant variant states of $\mathrm{Mm}(\mathrm{i})$. A new gathering of four leaves, a(tilde), substituted for A1, distinguishes 1 st and 2 nd issue. He also provides evidence for two textually significant cancels, Bb8,Ff2

10

L0235556 636

LE IEUNE, PavI

Relation de ce qui s'est passe. . .1637

Roven,

Chez lean Le Bovlanger. El se vendent a Paris, Chez Pierre De Bresche.

1638

8 vo 336,256pp

McCoy distingishes 4 variations: $24,25,26,27$. This is McCoy 26 and 27 (2 distinct issues)

CaQMM CaOTU CaOOP

McCoy identifies a variant state of forme a(tilde) (0), which distinguishes two issues, but any or all other variant formes might be present in any of the 3 issues subsumed in McCoy's 24-27

11

L0235565 638

LE IEVNE, Pavle

Relation de ce qui s'est passe. . .1638

Paris,

Chez Sebastien Cramoisy.

1638

8vo 78,67pp

McCoy distinguishes 2 edns: 1st, 28; 2nd, 29,30

CaOTU CaQMM CaOTP 
The eighteenth-century bibliography is at a more primitive stage of development simply because no manually-produced bibliographical tool is available for us to make the computer, as yet, serve as a telescope of the mind. The highly-respected Bibliothèque de la Compagnie de Jésus, first published in $1853,{ }^{20}$ is the most comprehensive tool for bibliographical control of the writings of the Jesuits. Even the 1960 edition $^{21}$ of Sommervogel, who revised De Backer's monumental work, is limited by the fact that the entries in the bibliography are based on secondary sources and not on the books themselves. The 40 or so entries for the Lettres édifiantes et curieuses found under Gobien, Halde, Patouillet, and Querbeuf (nothing under Marechel or Marchal) are derived mainly from review notices such as those in the Journal de Trevoux, ${ }^{22}$ and the books listed need to be matched with actual copies. Thus, WHSTC 7, 16, 24, 44, 45 still need checking. Obvious gaps in the De Backer/Sommervogel lists (e.g. Vols 21-26, 29-30, 32) have been supplied in our bibliography, and information derived from NUC or individual library catalogs has been added to the query files for confirmation as well.

For instance, WHSTC 1, 40, and 41 not only record from NUC some abbreviated bibliographical information within square brackets, but also record the location of the copy closest to London, Ontario, that could be used to create a short-title catalog record for the main files.

40

J0093039 767

[see description in NUC]

[Memoires geographiques, Paris] [MiU]

41

J0093040 767

[this item not yet in control file]

[Memoires geographiques, Yverdon] [NN]

WHSTC 44 and 45 indicate that a visit to the Bibliothèque Nationale in Paris might be necessary in order to improve our bibliographical control.

44

J0093018* 90

[description not yet on file]

[Vol XXXI de Hansy le jeune 1774] [Bibliotheque nationale de la France]

45

J0093018* 95

[description not yet on file]

[Vols XXXIII-XXXIV Pierre Berton 1776] [XXXIII in BN de la France]

Locations information is, of course, a very important element in improving our bibliographical control of a portion of the bibliographical universe. The locations information for Canadian libraries is as complete as use of the Canadian Union Catalog (CANUC) and serendipity can make it, but it must be obvious that early editions of early volumes are scarcer than later editions or later volumes in the series.

Early editions of particular volumes seldom appear in complete sets of the 
Lettres, as they were long out of print when the sets were made up. It is ironic, therefore, that libraries that can boast of complete sets seldom have the earliest editions. One must look for broken or incomplete sets if one wants early editions. Item 3 , for instance, was found in the William L. Clements Library in a mixed set of volumes 1-4, 10-15, 17, 23, 25, and 27. The first three volumes came from a seminary in Guelph, Ontario, where, presumably, later volumes were not to be found.

Locations information is also an important element in our bibliographical instruments because the powerlessness of scholars in the past to find actual copies of the earliest editions has led to heavy reliance on nineteenth- and twentieth-century reprints or editions of the earlier texts. Selert bibliographies or primary sources (which scholarly practice demands should be included in an authoritative scholarly work) are very deficient in contemporaneous printed sources because of reliance on modern texts. Careful checking of the intermediary texts against the originals is not a common practice, and one suspects that this is because a copy of the originals is not easy to find. Locations information is too restricted in a library catalog, and tools such as Dionne do not have such information. As always, Tremaine is an honorable exception.

Indeed, the degree of bibliographical control provided by our bibliographical instruments is so poor that we cannot even estimate from them the total number of separate items that constitute French-language Canadiana in the eighteenth century nor what proportion of them are to be found in Canadian libraries. The definition of what constitutes an "item" differs considerably from one bibliographical tool to another, so the rough counts I have alluded to earlier are not very reliable. It seems almost certain, however, that manually-produced instruments give us more control over sixteenth and seventeenth-century French-language printed books than over eighteenth-century books (with the exception of Canadian imprints). The machine-based system which is now being developed as part of the WHSTC system is already more comprehensive than any one manually-produced tool and has indexing devices which provide more points of access or indexing capability than any one manually-produced tool. The data base does not yet incorporate material from Harrisse, Dionne, and other fairly comprehensive standard bibliographies, but it would, I think, be fitting to end this paper with the best estimate possible at this time of the size of that portion of the bibliographical universe that can be called French-language Canadiana of the eighteenth century. The WHSTC bibliographies you have seen demonstrate that the contents of the query file are automatically counted by the machine and printed out after the heading. The four query files containing lists of Canadiana show that, as of this moment, the number of items is as follows:

\begin{tabular}{ll}
$1545-1700$ & 188 \\
$1701-1750$ & 162 \\
$1751-1770$ & 190 \\
$1771-1800$ & 125 \\
\hline Total & 665
\end{tabular}


Comparison of the pre-1701 printout with Harrisse demonstrates that 92 are identifiable in WHSTC, and that 65 items in the best manually-produced tool available may, eventually, after confirmation, be added to the file. Twenty items in Harrisse are not relevant, but the ease with which judgments can be made about items in Harrisse shows what a fine tool the 1872 bibliography really is. But our machine-readable file more than doubles our exploitative and descriptive power. The answer to "How many items of printed French Canadiana were published before 1701" can be answered "At least 253." "What are they" can be answered with a printout of a developing bibliography. "Where are they" can also be answered (at least partly) by the same printout.

Similarly, for the first half of the eighteenth century, although comparison of the 1701-1750 WHSTC bibliography with Dionne reveals considerable inaccuracy in the 1906 bibliography, 62 items are identifiable with reasonable certainty. The 65 possible additions to WHSTC may eventually be reduced to about 50 when all "ghosts" have been laid. So it would seem possible to state "At least 212 items of French-language Canadiana were published in the eighteenth century before printing was introduced into Canada." After printing was introduced, approximately 580 French-language items were published in Canada, and at least 250 were published outside Canada.

When the query files have been further developed, I hope to be able to locate copies of as many items as possible in Canadian libraries. A recent sampling of U.S. libraries suggested that holdings as high as $46 \%$ could be found in the richest collection in the U.S. - in the John Carter Brown Library, Brown University, Providence, Rhode Island. Present indications are that no one collection in Canada is likely to provide more than $30 \%$ of the possible range of books. We need to improve our bibliographical control in order to improve our bibliographical resources.

William J. Cameron

The University of Western Ontario

\section{Notes}

' Ranganathan, Shiyali Ramamrita, "Universal Bibliography and its Substitutes" Libri 1953: 2: 293.

2 Ranganathan, Shiyali Ramamrita, ed, Documentation and its Facets; being a symposium of seventy papers by thirty-two authors, Bombay, New York, Asia Pub. House, [1963] 639p.

${ }^{3}$ Cameron, William J. Bibliographical Control of Early Books, Bangalore, India, Sarada Ranganathan Endowment for Library Science, 1978. ix, 78p.

${ }^{4}$ Wilson, Patrick, Two Kinds of Power, An Essay on Bibliographical Control, Berkeley and Los Angeles, Univ. of California Press, 1968.

5 Tremaine, Marie, A Bibliography of Canadian Imprints 1751-1800, Toronto, University of Toronto Press, 1952. xxvii, 705p.

- Dionne, Narcisse-Eutrope, Inventaire chronologique des livres . . publiés en langue française dans la province de Québec. . 1764-1905, Québec, 1905 viii, 175p. (And Premier Supplément 1912).

7 Dionne, Narcisse-Eutrope, Inventaire chronologique des ouvrages publiés à l'étranger . . . sur Québec et la Nouvelle France ... 1534-1906, Québec, 1906. viii, 155p (And Premier Supplément, 1912.) 
${ }^{8}$ Staton, Frances M. and Marie Tremaine, A bibliography of Canadiana, Being items in the Public Library of Toronto, Canada, relating to the early history and development of Canada, Toronto, The Public Library, 1934. 828p.

9 Gertrude M. Boyle and Marjorie Colbeck, A bibliography of Canadiana First Supplement, Being items in the Public Library of Toronto, Canada, relating to the early history and development of Canada, Toronto, The Public Library, 1959, 333p.

10 The National Union Catalog: Pre-1956 Imprints, London, Mansell, 1968-, 674 vols + (still appearing).

"Boivin, Henri-Bernard, compiler, Bibliographie de bibliographies québécoises, Montréal, Ministre des affaires culturelles, Bibliothèque nationale du Québec, 1979. 2 vols.

12 Lochhead, Douglas, Bibliography of Canadian Bibliographies. Index compiled by Peter E. Greig Second edition, [Toronto], University of Toronto, in association with the Bibliographical Society of Canada, [1972]. 312p.

${ }^{13}$ Vlach, Milada, and Yolande Buono, compilers, Laurentiana parus avant 1821. Montréal, Bibliothèque nationale du Québec, 1976. xxvii, 413,120p.

14 Lande, Lawrence. The Lawrence Lande collection of Canadiana in the Redpath Library of McGill University Montreal, Lawrence Lande Foundation for Canadian Historical Research, 1965. xxxv, 301p.

is McGill University, Rare and Unusual Canadiana; first supplement to the Lande bibliography, Montreal, Lawrence Lande Foundation for Canadian Historical Research, 1971. xx, 779p.

16 McCoy, James Comly, Jesuit Relations of Canada, 1632-1673; a bibliography, Paris, Arthur Race, 1937. 310p.

${ }^{17}$ Cameron, William J., The HPB Project: Phase IV. The French Canadian Contribution to the Development of A Western Hemisphere Short-Title Catalog (WHSTC) of Spanish, French, and Portuguese books printed before 1801. London, Ontario, University of Western Ontario, 1980 , vi, 183, [128]p.

${ }_{18}$ Harrisse, Henry, Notes pour servir à l'histoire, à la bibliographie et à la cartographie de la Nouvelle France et des pays adjacents 1545-1700, Paris, Librarie Tross, 1872, xxxiii, 367p.

19 Conlon, Pierre, Prélude au siècle des lumières en France: Répertoire chronologique de 1680 à 1715, Genève, Droz, 1970-75, 6 vols.

${ }^{20}$ De Backer, Augustin, Bibliothèque des écrivains de la Compagnie de Jésus, Liège, Grandmont-Donders, 1853-1861. 7 vols.

${ }^{21}$ De Backer, Augustin et Alois, Bibliothèque des écrivains de la Compagnie de Jésus; nouvelle édition par Carlos Sommervogel, Heverlé-Louvain, Editions de la Bibliothèque S.J., 1960. 12 vols.

${ }^{22}$ Mémoires pour l'histoire des sciences et des beaux-arts. Trévoux, Impr. de S.A.S. Paris, Chez E. Ganeau, 1701-67. 265 vols. 